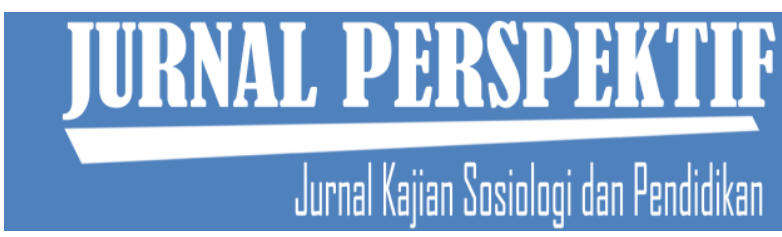

Jurnal Perspektif: Jurnal Kajian Sosiologi dan Pendidikan Vol. 3 No. 3 Tahun 2020

http://perspektif.ppj.unp.ac.id

Email: perspektif@ppj.unp.ac.id

ISSN: 2622-1748 (Online), 2684-902X (Print)

DOI: http://dx.doi.org/10.24036/perspektif.v3i3.288

\title{
Hambatan Pelatihan Program Satuan Pendidikan Aman Bencana (SPAB) oleh Badan Penanggulangan Bencana Daerah Provinsi Sumatera Barat
}

\author{
Melvia Melvia', Zikri Alhadi ${ }^{2}$ \\ 1,2 Universitas Negeri Padang \\ Email: viamel092@gmail.com, the.zikrialhadi@gmail.com
}

\begin{abstract}
Abstrak
Penelitian ini menjelaskan tentang hambatan penerapan pelatihan Satuan Pendidikan Aman Bencana (SPAB) oleh Badan penanggulangan Bencana Daerah Provinsi Sumatera Barat. jenis penelitian ini menggunakan data kualitatif dengan metode deskriptif. Yang mana dalam penelitian ini hanya terdapat 1 variabel yaitu pelaksanaan pelatihan Satuan Pendidikan Aman Bencana. Data yang penulis dapatkan melalui pengamatan, wawancara dan dokumentasi. dengan teknik analisis data yaitu reduksi data, penyajian data dan penarikan kesimpulan. Berdasarkan hasil penelitian dapat diketahui bahwa ada beberapa hambatan dalam pelatihan SPAB atau masalah yang menyebabkan pelatihan SPAB belum efektif. hambatan dalam pelatihan SPAB ini adalah keterbatasan dana pelatihan, kurangnya keseriuasan peserta dalam mengikuti pelatihan sampai selesai, serta pelatihan SPAB dianggap tidak terlalu penting dan paradigma berpikir peserta yang masih responsif.
\end{abstract}

Kata Kunci: Bencana, Hambatan, Pelatihan SPAB.

\section{Abstract}

This research tries to explain about the barriers to Disaster Safe Education Unit Training Programs by the west Sumatra provincial disaster management agency. Type of research is qualitative with descriptive methods. This research has one variable namely the implementation of the SPAB training program. Type of data collection by observation, interview and documentation study. Data analysis with data reduction, data presentation ang drawing conclutions. The obstacles in SPAB training or problems that cause SPAB training has not been effective. The obstacles in this SPAB training are he SPAB training budget is limited, the lack of seriousness of the participants in attending the training until completion, SPAB training is considered not too important and participant paradigms that are still responsive.

Keywords: Constraints, Disaster, SPAB training Program.

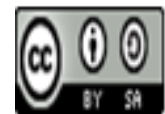




\section{Pendahuluan}

Bencana adalah kejadian yang dapat menyebabkan banyak kerugian, baik kerugian di bidang ekonomi, pendidikan sosial maupun budaya. Bencana merupakan suatu kejadian yang tidak akan dapat diduga kapan akan terjadi sehingga terkadang masyarakat tidak mengetahui cara bertindak untuk mengadapi bencana tersebut karena dipenuhi dengan rasa panik dan kurangnya pengetahuan tentang pengurangan resiko bencana .(Paidi, 2012). Dampak bencana di bidang pendidikan dapat mengakibatkan banyaknya korban jiwa yakni peserta didik, terhentinya proses belajar mengajar rusaknya sarana dan prasarana di sekolah serta hilangnya dokumen sekolah. Oleh karena itu pendidikan pengurangan resiko bencana perlu dilakukan di seluruh sekolah. Management berasal dari kata to manage yang berarti mengatur, dalam mengurangi dampak bencana diperlukan menagemen yang tepat untuk mengatur tindakan apa yang akan dilaksanakan. (Wijaya \& Rifa'i, 2016). Dalam pengurangan resiko bencana, manajemen sangat diperlukan agar kegiatan yang dilaksanakan dapat terkontrol dengan baik. Untuk itu pemerintah Republik Indonesia melalui Badan Penanggulangan Bencana Daerah Provinsi Sumatera Barat membuat sebuah kebijakan yaitu pelaksanaan pelatihan Satuan Pendidikan Aman Bencana (SPAB). Pelatihan SPAB ini di bentuk dalam upaya untuk pengurangan resiko bencana di bidang pendidikan.

Badan Penanggulangan Bencana Daerah Provinsi Sumatera dalam menjalankan kegiatan pelatihan SPAB. Bagian BPBD Sumatera Barat yang memiliki wewenang atau yang bertanggung jawab adalah bidang Pencegahan dan Kesiapsiagaan (PK) yang dipimpin oleh Syahrasad Jamil, S.H., M.M dengan Kasubid Pencegahan Indraveri S.Sos.,M.Kes. kasubid Kedaruratan Suryadi,S.Kom dengan 9 orang staff yaitu Eva Trisna.,S,T.,M.Si , Ferry S.T, Yusra Agustin, S.T, Fivtinia Octagsni, S.S,Yeffi Alfian, Isrin, Muklizen, Rahmi Dwi Liza, Alpiyanti. Sedangkan fasilitator pelatihan program Satuan Pendidikan Aman Bencana yang memfasilitasinya adalah Forum PRB Sumatera Barat. jadi seluruh narasumber pelatihan SPAB adalah mereka yang tergabung dalam Forum Pengurangan Resiko Bencana Provinsi Sumatera Barat.

Pelatihan SPAB ini dilaksanakan mulai dari tahun 2017. Sasaran dari program pelatihan SPAB adalah seluruh sekolah tingakt SLTA di Sumatera Barat yang berada di daerah rawan bencana. Pelatihan SPAB ini dilaksanakan dengan berbagai tahap. Hal ini karena anggaran pelatihan yang sangat terbatas untuk memberikan pelatihan Satuan Pedidikan Aman Bencana (SPAB) ke seluruh sekolah SLTA yang ada di Sumatera Barat. Bentuk pelatihan Satuan Pendidikan Aman Bencana (SPAB) ini adalah Workshop atau pemberian materi kebencanaan kepada peserta pelatihan tujuan untuk meningkatkan pengetahuan para peserta pelatihan dalam pengurangan resiko bencana sehingga setelah mendapatka pelatihan diharapkan mereka dapat menjadi tular informasi kepada para siswa di sekolah sehingga jika seandainya terjadi bencana mereka warga sekolah sudah mengetahui bagaimana cara bertindak yang tepat dalam menghadapi bencana sehingga dampak dari bencana atau korban jiwa dapat dimimalisir. Pelaksanaan pelatihan program Satuan Pendidikan Aman Bencana (SPAB) ini dilandaskan pada Peraturan Kepala BNPB Nomor 4 Tahun 2012 Tentang Pedoman Penerapan Sekolah/Madrasah Aman Bencana (Rawan dkk., 2011).

BPBD Provinsi Sumatera Barat dalam menjalankan pelatihan Satuan Pendidikan Aman Bencana (SPAB merupakan upaya untuk mengurangi resiko bencana di bidang pendidikan. Kenyataan dilapangan masih terdapat beberapa hambatan dalam pelaksanaan pelatihan SPAB hal ini dikarenakan kurangnya keseriusan peserta dalam mengikuti pelatihan sampai selesai serta paradigma berpikir peserta yang tidak responsive terhadap pelatihan Satuan Pendidikan Aman Bencana. 


\section{Metode Penelitian}

Penelitian ini menggunakan data kualitatif dengan metode desriptif. (Febriawati et al., 2017). Pemilihan informan pada penelitian ini memakai metode purpose sampling untuk. Penelitian ini dilakukan pada Badan Penanggulangan Bencana Daerah (BPBD) Provinsi Sumatera Barat sebagai instansi pelaksana pelatihan SPAB. Adapun sumber data yang peneliti peroleh dengan cara pengamatan, wawancara, interviu/tanya jawab serta studi dokumentasi (Erdina \& Hariani, 2017). Sedangkan teknik analisis data yang penulis gunakan adalah reduksi data, penyajian data dan penarikan kesimpulan atau verifikasi.

\section{Hasil dan Pembahasan}

Kebijakan ataupun program dapat dikatakan efektif apabila telah mencapai tujuan sesuai dengan yang telah ditetapkan (Nasila, 2013). Didalam menjalankan suatu kebijakan ataupun pelatihan tidak akan terlepas dari hambatan atau kendala yang menjadi penghambat untuk mencapa kefektifan dari program tersebut. Efektivitas pelatihan SPAB pada penelitian ini peneliti ukur dengan menggunakan teori Nakamura (Nurlaela \& Hariani, 2016). yang terdiri dari 5 dimensi yakni pencapaian tujuan, Efisiensi, Kepuasan Kelompok sasaran, daya tanggap klien dan sistem pemeliharaan Berdasarkan pengamatan yang sudah dilakukan secara keseluruhan efektivitas dari pelatihan Satuan Pendidikan Aman Bencana (SPAB) belum sepenuhnya dapat tercapai, dikarenakan masih terdapat beberapa hambatan ataupun kendala yang ditemui dalam pelaksanaan pelatihan SPAB ini. adapun hambatan atau kendala tersebut antara lain:

Pertama, terbatasnya anggaran pelatihan Satuan Pendidikan Aman Bencana (SPAB). Tidak dapat dipungkiri bahwa ketersediaan anggaran dalam melaksanakan sebuah pelatihan ataupun kegiatan merupakan faktor yang paling penting. Efektivitas suatu kebijakan harus didukung dengan ketersediaan anggaran yang sesuai sehingga elatihan SPAB itu dapat terimplrmrntasikan dengan baik sehingga pelatihan tersebut dapat tercapai dengan efektif. (Nuraeni, 2017). Anggaran yang tidak memadai dalam melaksanakan sebuah pelatihan mempengaruhi ketercapaiannya tujuan yang akan hendak dicapai, mengingat ada 700 sekolah yang akan diberi pelatihan jadi agar tercapainya tujuan yang telah ditetapkan sebelumnya secara maksimal tentu akan membutuhkan dana yang seimbang atau sesuai agar tujuan tersebut dapat tercapai. Namun pada pelaksanaan pelatihan SPAB anggaran yang ada masih kurang untuk dapat melaksanakan pelatihan SPAB dalam satu atau beberapa angkatan saja. Kendala tersebut menyebabkan BPBD Sumatera Barat selaku pelaksana harus menyesuaikan kegiatan dengan anggaran yang ada. Tindakan yang dilakukan oleh BPBD Provinsi Sumatera Barat adalah dengan melaksanakan pelatihan SPAB secara bertahap, yang dalam satu tahap terdiri dari 25 sekolah dan yang menjadi peserta pelatihan SPAB, tujuannya agar seluruh sekolah SLTA yang ada di Sumbar mendapatkan pelatihan SPAB ini secara merata sehingga tujuan pelaksanaan pelatihan SPAB dapat tercapai dengan maksimal.

Hambatan kedua adalah kurangnya keseriusan para peserta pelatihan Satuan Pendidikan Aman Bencana (SPAB) dalam mengikuti kegiatan sampai selesai. Partisipasi peserta menjadi hal yang sangat dibutuhkan untuk mencapai keefektifam pelatihan SPAB ini (Kogoya dkk., 2015).Partisipasi atau keseriusan peserta dalam menjalankan pelatihan sangat dibutuhkan dalam mencapai tujuan dari pelatihan ini. karena tanpa adanya keseriusan dari 2 belah pihak pelatihan ini akan sangat sulit untuk dilaksankan. Karena pada dasarnya sitem pelatihan ini adalah tidak berbentuk fisik namun bentuknya hanya memberikan pengetahuan terkait materi pengurangan resiko bencana yang berpedoman kepada 3 pilar yakni sarana dan prasaran yang 
aman bencana, manajemen bencana di sekolah dan pengetahuan kebencanaan kepada warga sekolah.

Keseriusan dan partisipasi peserta dalam mengikuti pelatihan ini belum di anggap baik, dimana sebagian besar peserta yang menjadi sasaran utama pelatihan SPAB belum berperan aktif dalam mengikuti pelatihan SPAB dari awal sampai selesainya kegiatan. Pada saat melaksanakan pelatihan sebagian besar peserta pelatihan banyak yang meminta izin untuk keluar alasannya untuk mengerjakan pekerjaan lain diluar pelatihan SPAB padahal yang menjadi peserta pelatihan SPAB itu sudah mendapatkan surat tugas ataupun SPPD untuk mengikuti pelatihan sampai selesai. Fenomena ini tentu menjadi hambatan untuk tercapainya keefektifan dari pelatihan Satuan Pendidikan Aman Bencana (SPAB) sesuai dengan tujuan yang telah ditetapkan.

Hambatan ketiga adalah Pelatihan Satuan Pendidikan Aman Bencana (SPAB) belum dianggap penting oleh peserta dan paradigma berpikir peserta yang masih tidak responsive terhadap pelatihan Satuan Pendidikan Aman Bencana (SPAB). Respon dari peserta terhadap pelatihan SPAB sangat dibutuhkan karena ini juga sangat menentukan bagaimana keefektivan dari pelatihan SPAB ini. tanpa adanya respon yang baik dari peserta pelatihan ini akan sangat sulit untuk mencapai kesuksesan dari pelatihan ini. pelatihan Satuan Pendidikan Aman Bencana (SPAB) ini masih dianggap tidak penting dan paradigma berpikir peserta yang tidak responsif terhadap pelatihan SPAB, hal ini karena pelatihan Satuan Pendidikan Aman Bencana (SPAB) yang diberikan ini bersifat fisik yakni hanya sekedar memberikan pengetahuan kepada para peserta tentang pengurangan resiko bencana, oleh karena itu pelatihan ini mereka anggap sebagai suatu hal yang membosankan. Dengan paradigma berpikir para peserta pelatihan SPAB yang seperti itu menjadi hambatan bagi Badan Penanggulangan Bencana Daerah (BPBD) Provinsi Sumatera Barat untuk mencapai keberhasilan pelatihan secara maksimal.

\section{Kesimpulan}

Setelah melakukan penelitian dan mendapatkan hasil dari penelitian serta telah melakukan pembahasan terkait hasil tersebut, dapat disimpulkan bahwa dalam pelatihan Satuan Pendidikan Aman Bencana (SPAB) terdapat beberapa kendala dalam melaksanakan kegiatan pelatihan SPAB ini, adapun hambatan ataupun kendala dalam efektivitas pelatihan Satuan Pendidikan Aman Bencana (SPAB) oleh Badan Penanggulangan Bencana Daerah Provinsi Sumatera Barat adalah terbatasnya ketersediaan anggaran pelatihan SPAB yang menyebabkan instansi pelaksana yakni BPBD provinsi Sumatera Barat harus menyesuaikan dengan anggaran yang ada, faktor penghambat kedua adalah kurangnya keseriusan peserta pelatihan SPAB dalam mengikuti seluruh kegiatan pelatihan sampai selesai. Hambatan ketiga adalah Pelatihan Satuan Pendidikan Aman Bencana dianggap tidak terlalu penting serta paradigma berfikir peserta pelatihan yang tidak responsif terhadap kegiatan pelatihan SPAB. Dari hambatan Pelatihan SPAB yang ada mengakibatkan efekivitas pelatihan Satuan pendidikan Aman Bencana yang dilaksanakan oleh Badan Penanaggulangan Bencana Daerah (BPBD) Provinsi Sumatera Barat secara keseluruhan belum efektif.

\section{Daftar Pustaka}

Erdina, T. V., \& Hariani, D. (2017). Analisis Efektivitas Organisasi Dalam Program Pelayanan Administrasi Terpadu Kecamatan (PATEN) di Kecamatan Gunungpati Kota Semarang. Journal of Public Policy and Management Review, 6(3), 334-354. https://doi.org/https://doi.org/ 10.14710/jppmr.v6i3.16794

Febriawati, H., Angraini, W., Ekowati, S., \& Astuti, D. (2017). Analisis Manajemen Bencana 
Gempa Di Rumah Sakit Umum Daerah Dr. M. Yunus Kota Bengkulu. Ilmu Kesehatan Masyarakat, 8(1), 28-33.

Kogoya, T., Olfie, B., \& Laoh, O. E. (2015). Partisipasi Masyarakat Terhadap Pembangunan Infrastruktur Jalan Desa di Kabupaten Lanny Jaya-Papua. Berkala Ilmiah Efisisensi, 15(2), 1-14.

Nasila, J. W. (2013). Efektivitas Program Daerah Pemberdayaan Masyarakat (PDPM), Studi Tentang Penanggulangan Kemiskinan di Kelurahan Mamboro Kecamatan. Jurnal Academica Fisio Untad, 6(2), 1253-1264.

Nuraeni, A. S. I. (2017). Implementasi Kebijakan Penyusunan Anggaran Pendapatan dan Belanja Daerah Kabupaten Mamuju Utara. Jurnal Katalogis, 5(1), 55-64.

Nurlaela, I., \& Hariani, D. (2017). Analisis Efektvitas Program Revitalisasi Pasar Tradisional Di Pasar Bulu Kota Semarang. Journal of Public Policy and Management Review, 6(2), 515-531.

Paidi. (2012). Pengelolaan Manajemen Risiko Bencana Alam di Indonesia. Jurnal Ilmiah Widya, 37-46.

Rawan, K., Di, B., Sulawesi, P., \& Lereng, P. (2011). Pendekatan Untuk Menentukan Kawasan Rawan Bencana di Pulau Sulawes. Jurnal Sabua, 3(3), 40-52.

Wijaya, D.C, \& Rifa'i, M. (2016). Dasar Dasar Manajemen Mengoptimalkan Pengelolaan Organisasi Secara Efektif dan Efesien (Cetakan pertama). Medan: Perdana Publishing. 